\title{
The Lucio-Alvarado-Latapi form of leprosy
}

\author{
MARIA J. N. DIOGENES*, RAQUEL M. DE MORALS*, \\ GERALDO DE S. TOMÉ**, MARCOS B. DA CUNHA ${ }^{\dagger}$ \\ \& CARLOS DA C. B. NETO ${ }^{\dagger \dagger}$ \\ *Dermatological Service, Walter Cantidio Hospital, Federal \\ University of Ceará (WCH-FUC), \\ ${ }^{* *}$ Pathology and Legal Medicine Department, FUC, ${ }^{\dagger}$ Neurological \\ Service, WCH-FUC and ${ }^{\dagger \dagger}$ Haematological Service, WCH-FUC, Rua \\ Ana Bilhar, 601/400, Meireles, CEP: 60160-110, Fortaleza, Ceará, \\ Brasil
}

\section{Introduction}

Lucio's leprosy is characterized clinically by diffuse, generalized, erythematous infiltration with no nodules. Other clinical manifestations are rhinitis, alopecia, telangiectasia of face and chest, facial acne rosacea and livedo on the lower limbs. ${ }^{1-3}$ Skin smears for acid-fast bacilli are positive from any site, since bacterial infection is diffuse. The histopathology shows characteristic features of diffuse granuloma Virchow cell infiltration and new vascular formation. ${ }^{1,2}$

This variety of leprosy may be accompanied by Lucio's phenomenon characterized by multiple and acute necrotizing lesions. ${ }^{4-7}$

Treatment with multi-drug therapy (rifampicin, dapsone and clofazimine) has proved satisfactory with clinical improvement. ${ }^{1-3}$ Corticosteroids are prescribed when Lucio's phenomenon is present. $^{6-8}$

\section{Case report}

A 52-year-old white man from Crato-Ceará-Brazil presented to the outpatient dermatology clinic at Walter Cantideo University Hospital with erythematous skin lesions. He had a history of syphilis treated with penicillin 16 years earlier and focal glomerulosclerosis with nephrotic syndrome for 8 years. He was taking prednisone $(0.25-1.0 \mathrm{mg} / \mathrm{kg} /$ day $)$, frusemide and ranitidine. Examination revealed diffusely erythematous and infiltrated skin; telangiectasia on face and chest; alopecia of chest; violet-erythematous livedo on lower limbs and coalescent yellow maculae of irregular surface on his enlarged nose. There was no nerve involvement.

Investigation showed: acid fast bacilli on three skin smears (chest wall, neck and thighs) and smears from ear lobe and elbow: bacteriological and morphological indexes were not 
performed because at the time of diagnosis, Brazil's Health Ministry did not require them for diagnosis. Other tests included erythrocyte sedimentation rate $(75 \mathrm{~mm})$, fluorescent treponemal antibody [absorbed test (FTA-ABS) (-ve)], Veneral Disease Research Laboratory test (VDRL) (1:2), antinuclear antibody (-ve), Mitsuda (-ve), Medina (-ve), cryoglobulin (-ve), haemoglobin at the time of presentation $(14.8 \mathrm{mg} / \mathrm{dl})$, white cell count range at the time of presentation $\left(9500 / \mathrm{mm}^{3}\right)$, serum creatinine $(1 \cdot 1 \mathrm{mg} / \mathrm{dl})$ and serum glucose $(80 \mathrm{mg} / \mathrm{dl})$. Alanine and aspartate aminotransferases, complement, search for parasites in faeces and protein electrophoresis showed no abnormalities.

Skin biopsy from the nose revealed inflammatory infiltration with numerous bacilli and significant hyperplasia of sebaceous glands. Renal biopsy showed focal glomerulosclerosis. Three skin biopsies from chest, neck and thighs demonstrated the papillary layer of the dermis as a clear band. Deeper in the dermis, there was diffuse inflammatory infiltration with 'foamy' macrophages with no nodule formation. Vascular proliferation was visible under H\&E staining and numerous bacilli forming globi were observed with Wade-Fite staining.

Multidrug therapy treatment was started and by 3 months there was remission of erythema with wrinkling of the skin. Skin smears showed fragmented bacilli and a skin biopsy from the chest wall showed resolution of the inflammatory infiltration with numerous bacilli. After 2 years of multidrug therapy, the infiltration of skin had regressed and there was diffuse hyperpigmentation due to clofazimine. Skin smears were negative. The nephropathy was well controlled with prednisone $(0 \cdot 25-1 \mathrm{mg} / \mathrm{kg} /$ day $)$.

\section{Discussion}

The diagnosis of Lucio's leprosy is difficult because in many cases the patient has no clear signs of leprosy. In this case, other factors contributed to the diagnostic difficulty. Firstly, the association with rinophyma and telangiectasia obscured the clinical perception of leprosy. Secondly, the use of glucocorticoids to control renal disease probably altered the progression of leprosy, possibly inhibiting a Lucio's phenomenon. Thirdly, there was the probable wrong diagnosis of syphilis and treatment with penicillin 16 years ago; the patient had a positive Veneral Disease Research Laboratory test but negative fluorescent treponemal antibodyabsorbed test, which is more specific. The patient probably already had Lucio's leprosy at that time with a false positive VDRL test. There has been evidence that a false-positive VDRL with intense reactions occurs constantly in Lucio's leprosy. ${ }^{1,3}$ A study carried out in Mexico demonstrated $16 \%$ of false-positive VDRL in the sera of 25 patients with diffuse lepromatous leprosy. ${ }^{7}$

The diagnosis of this case was based on clinical and microscopic features. Clinically, there was diffuse erythematous infiltrated skin, with telangiectasia, livedo on lower extremities, alopecia in some areas of the skin and a long evolution without the appearance of definite nodules or plaques. On microscopic examination, diffuse granulomatous, Virchow cell infiltration and new vessel formation were observed.

The occurrence of Lucio's leprosy in countries other than Mexico and Costa Rica is rarely described, although there have been reports of cases in California, Louisiana, Hawaii and Minas Gerais-Brazil. ${ }^{1,2,5}$ It is interesting that this case was diagnosed in a patient from the city of Crato-Ceará-Brazil, which has a very high prevalence of leprosy. Thus it is possible that more cases of this form of leprosy are yet to be diagnosed. 


\section{References}

${ }^{1}$ Latapi F, Zamora AC. La lepra manchada de Lucio (estudio inicial clinico e histopatologico). Int J Lepr, 1948; 16: 421-429.

${ }^{2}$ Furtado T. The Lucio-Alvarado form of leprosy. A case observed in Brazil. Int J Lepr, 1959; 27: 110-115.

3 Talhari S, Neves RG. Manif estações cutâneas e diagnóstico diferencial. In: Talhari S, Neves RG (eds) Hanseniase 2a. ed. ISEA, Manaus, 1989, pp 5-35.

4 Calux MIF. Contribuiçao a o estudo do eritema necrosante (Fenômeno de Lücio) na hanseniase (tese). Faculdade de Medicina de Sao Paulo (USP), 1989.

5 Donner RS, Shively JA. The 'Lucio phenomenon' in diffuse leprosy. Ann Int Med, 1976; 67: 831-835.

6 Pardo-Castello V, Caballero GM. Lazarine leprosy: a peculiar monosymptomatic form of leprosy. Arch Dermatol Syphiol, 1931; 23: 1-11.

7 Ortiz Y, Giner M. Avances recientes en la lepra de Lucio. Revista Mexicana de Dermatologia, 1978; 22: 141-163.

${ }^{8}$ Mazzini MA. Lepra. In: Mazzini MA (ed.) Dermatologia Clinica. Lopes Liberos Editores, Buenos Aires, 1977, p. 615 . 